\title{
Insecticidal Efficacy of Methanol Extract of Leaves of Saraca indica L. against Four Insect Pests Causing Severe Damage to Stored Grains
}

\author{
Savita $^{1}$, Rimhim Sheel ${ }^{1}$, Baidyanath Kumar ${ }^{2 *}$ and Kumari Snehlata ${ }^{1}$ \\ ${ }^{1}$ Department of Botany, Ganga Devi Mahila College (Magadh University), \\ Kankarbagh, Patna-800020, India \\ ${ }^{2}$ Department of Biotechnology, Patna Science College, Patna (Patna University), \\ Patna-800005, India \\ *Corresponding author
}

A B S T R A C T

\section{Keywords}

Saraca indica, Leaf extract, Ostrinia nubilalis, Spodoptera littoralis, Callosobruchus maculates, Tribolium confusum, LC50, Larvicide, Ovicide

\section{Article Info}

Accepted: 06 May 2018 Available Online: 10 June 2018
The methanol extract from leaves of Saraca indica was investigated to control insect infestation of stored food commodities viz. maize, rice, cowpea and wheat flour during from Ostrinia nubilalis, Spodoptera littoralis, Callosobruchus maculates and Tribolium confusum. After introducing the test insects, stored food samples were fumigated with methanol extract from leaves of Saraca indica at $500 \mu \mathrm{g} / \mathrm{mL}$ (ppm). The methanol extract significantly enhanced feeding deterrence in insects and reduced the grain damage as well as weight loss in fumigated food samples infested with all insects. The methanol extract at different doses significantly reduced oviposition and adult emergence of these insect pests. Regression analysis of data on individuals in treated food samples confirmed that significant reduction of oviposition and adult emergence of insect pests decreased with increase in doses. All the four insect pests caused minimum damage to food commodities when fumigated with methanol extract of leaves of Saraca indica. The methanol leaf extract of Saraca indica exhibited as botanical fumigant in protection of stored maize, rice, cowpea and wheat by enhancing feeding deterrence and reducing grain damage as well as weight loss of Ostrinus nubilalsis, Spodoptera littoralis, Callosobruchus maculatus and Tribolium confusum. The ovicidal activity of the methanol extract of leaves of Saraca indica against four insect pests reveals that no hatching of larvae were observed till 24 hours. Hatching of larvae were observed from 24 hours to 72 hours. No further hatching was recorded after 72 hour of treatment. Therefore LC50 value of ovicidal activity was recorded at 72 hour of exposure period. At $10 \mathrm{ppm}$ and after 72 hours of incubation $O$. nibilalsis, S. littoralis, C. maculatus and T. confusum the hatching percentage was $80.75 \%$, $78.51 \%, 76.25 \%$ and $78.85 \%$ respectively. The hatching of larvae showed a decreasing trend on increasing the concentration of methanol extract of Saraca indica. At 1000ppm concentration of leaf extract and after $72 \mathrm{hrs}$ of incubation the hatching percentage of $O$. nibilalsis, S. littoralis, C. maculatus and T. confusum was $26.15 \%, 21.16 \%, 22.18 \%$ and $24.15 \%$ respectively. The larvicidal activity of methanol extract of leaves of Saraca indica against four insect pests viz. Ostrinus nubilalsis, Spodoptera littoralis, Callosobruchus maculatus and Tribolium confusum was found to be directly related to the exposure time and concentration of the methanol extract. 


\section{Introduction}

Saraca indica L. (Ashok) is a small evergreen tree of sub family Caesulpinoideae of family Leguminosae. The leaves are paripinnate, oblong and and rigidly sub- coriaceus with 67 leaflets (Ali, 2008). This tree has orange coloured flowers with a beautiful aroma, 7- 8 stamens are found in flower and fruits are smooth, leathery and flat pods including 6- 8 seeds inside (Jain, 1968). Bark of this tree is rich in tannins, flavonoids, steroids, volatile oil, glycosides, and various steroidal glycosides. Leaves contain various carbohydrates, tannins, gallic acid and egallic acid. Flowers are rich in sarcasin, sarcadin, waxy substances, proteins, carbohydrates and steroids. Seeds of this plant contain various fatty acids like oleic, linoleic, palmitic and stearic acid.

Ashok tree has been an integral part of Indian history. It is commonly called a tree which is important to decrease our sorrows. It has got religious significance and is also worshipped by some people in parts of India. It has a number of medicinal properties hence used by physicians since centuries in Unani system of medicine along with Ayurveda (Kokate et al., 2007). It is primarily used for the management of female reproductive problems. Married women in India are known to eat Ashoka flower buds as a ritual to invoke deities for child protection as well as gynecological problems. Women suffering from menorrhagia drink a decoction on an empty stomach in the morning, which is prepared from the bark of Ashoka in water in combination with other herbs such as Terminalia chebula and Coriandrum sativum (Begum et al., 2014).

In leucorrhoea, the decoction of Ashoka bark in water and milk after evaporation of water is consumed by women. In India, Srilanka, Bangladesh and Pakistan Ashoka bark is used by womenfolk in treating menorrhagia, menstrual and uterine disorders (Mishra et al., 2013; Mollik et al., 2010).

Saraca indica is a rain- forest tree. It is native of Asia and South America. It is originally distributed in the central areas of Deccan plateau. It is also found in Western Ghats of the Indian subcontinent. It is also widely distributed in the center and the Eastern Himalayas and in the hills of Khasi, Garo and available in West Bengal. It is common to all parts of Indian and other countries. In India it is easily available in West Bengal, Kerala, Maharashtra, Andhra Pradesh and Meghalaya (Kokate et al., 2007; Prajapati et al., 2003).

This plant has cooling properties. It is very useful for the body to bring down excessive heat in the organs due to fatigue or hormonal imbalance. It helps to regulate blood composition and stabilize blood circulation making it optimally available to all the body parts. Its pain relieving action can help relieve painful dysmenorrheal, swelling and pain at any site of the body. In females it is very commonly used to regularize hormones and menstrual cycles. It improves the strength and stamina in young females having menstrual irregularities such as dysmenorrea and leucorrhea. Many at times a combination of Aloe vera and Ashok is given to females to improve their reproductive health and blood condition. Anemia which is very common health problem in females is also recovered with the right combination of herbs along with Ashok derivatives. It not only works on uterine structures but also helps to cleanse the system so that any kind of microbial infestation that may be causing leucorrhea and other associated infections in the reproductive organs in females can be checked.

Ashok is also a cardiac tonic that can act as a supportive therapy for people suffering from hypertension, circulatory problems, edema, congestive heart failure etc. Its bark has 
natural detoxification properties which make it very useful to improve skin complexion and keep the body free from toxins inside out. Its natural cleansing properties can help the body stay toxin free. When the body has a lot of toxic load free radicals are produced. These free radicals then start damaging the body cells and all signs of ageing, disease and malfunctions are produced. For general pitta aggravated states also, Ashok bark acts as a coolant and helps to relieve thirst, excessive burning sensation, anger, emaciation, sweating etc. These are all common signs of pitta aggravation which can be relieved with the use of Ashok bark in different ways. It also has some digestive properties. Common problems of digestion like bloating, flatulence, burping, colicky pain in abdomen, ascites etc. can be relieved with the use of Ashok. It is not exactly a direct indication of the herb but it does help because all diseases have root from a malfunctioning gut and digestive system overtime.

Cereals and pulses have great biological and nutritional value in developing countries, are lost upto 20-60 per cent by storage insect pests during storage (Arthur and Throne 2003; Babu et al., 2003; Shaaya et al., 1997). Post-harvest deterioration causes economic losses due to obvious decay and adverse changes in the odour, taste, appearance and nutrition value (Phillips and Burkholder 1984; Mondal and Port 1994; Arlian et al., 1996). In addition, the arthropods transfer bacteria and microscopic fungi of pathogen importance on stick on their bodies or disseminate them via faeces (Wilbur and Mills 1978, Hubert et al., 2004). During recent years considerable attention has been paid towards exploitation of plant materials in protection of food commodities from insect infestations. Extracts of some plant species viz. Lantana camara (Saxena et al., 1992), Illicium verum (Ho et al., 1995), Tithonia diversifolia (Adedire and Akinneye, 2004) have been reported to possess strong insecticidal activity against different storage insects. Plant derived products namely, azadirachtin from Azadirachta indica, pyrethrin from Chrysanthemum cinerariaefolium, carvone from Carum carvi and allyl isothiocynate from mustard and horseradish oil have been received global attention due to their pesticidal properties and potential to protect several food commodities (Hartmans et al., 1995; Ward, 1998; Varma and Dubey, 1999; Athanassiou et al., 2005). Essential oils produced by different plant genera have been reported to be biologically active and are endowed with insecticidal, antimicrobial and bio regulatory properties (Mishra and Dubey, 1994; Varma and Dubey, 1999; Dubey et al., 2004; Holley and Patel, 2005). The volatility and biodegradability of flavour compounds of angiosperm will be advantageous if they are developed as pesticide insecticide (French, 1985). There may be least chance of residual toxicity by treatment of food commodities with volatile substances of higher plant origin.

In the present investigation the larvicidal activity of methanol extract of leaves of Saraca indica (L.) was assayed on the Lepidopteran insects viz. Ostrinia nubilalis and Spodoptera littoralis and Coleopteran insects viz. Callosobruchus maculatus and Tribolium confusum. These insects are known to severely damage crops like maize (Zea mays), rice (Oryza sativa), cotton (Gossypium herbaceum), tobacco (Nicotiana tabaccum), soybean (Glycine max), cowpea (Vigna unguiculata), rice (Oryza sativa), wheat (Triticum aestivum) and wheat flour on storage.

\section{Materials and Methods}

\section{Rearing and maintaining insect pests}

The lepidopteran insects like Ostrinia nubilalsis (European corn borer) and 
Spodoptera littoralis (Cotton leaf worm) were reared and maintained on maize and rice grains respectively. Similarly, Coleopteran insects Callosobruchus maculatus (Cowpea seed beetle) and Tribolium confusum (confused flour beetle) were reared and maintained on cowpea (Vigna unguiculata) grains and wheat flour respectively. The insects were maintained and reared at $27 \pm 2^{\circ} \mathrm{C}$ and relative humidity $(\mathrm{RH})$ of $80 \pm 5 \%$ following the methods suggested by Babu et al., (2003), Jenkins et al., (2003), PerezMendoza et al., (2004) and Arivoli et al., (2011).

Forty adult insects were released separately in $200 \mathrm{~g}$ of commodities (maize/rice/ cowpea/wheat flour) in plastic containers covered by muslin cloth. After 24 hours, adult insects were removed and the commodities were incubated in a temperature/humidity controlled cabinet $\left(27 \pm 2{ }^{\circ} \mathrm{C}\right.$ and $\left.\mathrm{RH} 80 \pm 5 \%\right)$ in darkness to obtain same aged insects. Adult insects were 2- 4 days old when used in the bioassays. Larvae were fed on larval food (powdered dog biscuit and yeast in the ratio 3:1) and adult mosquitoes on 10 per cent glucose solution. Pupae were transferred to a disposable cup and it is kept inside the cage.

\section{Preparation of methanol extract}

The leaves of Saraca indica were collected from the local garden of Ganga Devi College, Patna. Leaves were then sliced and chopped into small pieces, dried under shade and powdered with the help of a hand grinder, weighed and placed in separate conical flasks to add solvents. Methyl alcohol $\left(\mathrm{CH}_{3} \mathrm{OH}\right)$ (Merck, Germany) was used to prepare methanol extract from leaves. The dried plant sample was soaked with absolute methanol under reflux condition for the methanolic extract preparation. The sample was homogenized with extraction buffer. The supernatant was collected after three rounds of extraction. The solvent was evaporated under reduced pressure in a rotary evaporator at $40^{\circ} \mathrm{C}$. To this thick paste colloidal silicon dioxide was added and dried in vacuum tube dryer. The extract was then stored in deep freezer at $-20^{\circ} \mathrm{C}$ until further test.

Fumigation of maize, rice, cowpea and wheat flour by methanol extract Saraca indica

The methanol extract of leaves of Saraca indica was used to fumigate the maize, rice, cowpea and wheat grains samples separately by the method adapted by Shaaya et al., (1997) and Kumar et al., (2007). Five hundred gram of samples of each was kept separately in closed plastic containers $(35 \mathrm{~cm}$ diameter $\mathrm{x}$ $16 \mathrm{~cm})$. Care was taken to use uninfested freshly harvested grains and freshly prepared wheat flour. Twenty five individuals of each insect species viz. Ostrinia nubilalis, Spodoptera littoralis, Callosobruchus maculates and Tribolium confusum of mixed sex were introduced in the containers. Requisite amount of the methanol extract of Saraca indica was introduced separately in the plastic containers of each of the varieties by soaking in cotton swab so as to procure concentration of $500 \mathrm{ppm}$. The containers were made airtight.

The grains and flour inoculated with the test insects without methanol extract served as controls. After 24 months of storage at laboratory conditions in a temperature/humidity control cabinet (27 \pm $2{ }^{\circ} \mathrm{C}$ and $\mathrm{RH} 80 \pm 5 \%$ ) in darkness the efficacy of Saraca indica extract on insect infestation was determined by calculating grain damage $(\%)$, weight loss $(\%)$ and feeding deterrence $(\%)$ of treated and control sets.

The grain damage was determined by counting feeding injuries and emergence holes on the surface of the grains. The weight loss (\%) of 
samples in the treated and control sets was calculated by fresh weight basis using the formula suggested by Parkin (1956).

Weight loss $(\%)=\frac{\text { WI }- \text { W }}{\text { W }}$

Where WI and W represents the weight of grains before and after the experiment, respectively

Feeding deterrence was calculated using the feeding deterrent index following Isman (1990):

$\mathrm{C}-\mathrm{T}$
Feeding deterrent index (FDI) $[\%]=---\mathrm{X} 100$
$\mathrm{C}+\mathrm{T}$

Where $\mathrm{C}$ and $\mathrm{T}$ is the weight loss in the controls and in the fumigated sets, respectively.

\section{Insects Ovicidal Bioassay}

The ovicidal bioassay was performed according to the method described by Tennyson et al., (2011) and Puspanathan et al., (2006) with little modifications. For the ovicidal bioassay, 50 eggs of each species were transferred to each of the three replicates of each concentration.

Eggs were exposed to the DMSO and water was treated as control. For determination of LC50 values, a wide numbers of concentrations of the oils were tested against the target species. The number of eggs hatched in control and treatments were recorded and the percentage of ovicidal activity was calculated by the following formula-

Percent of eggs hatched in control Percent of eggs hatched in treated Percent Ovicidal activity $=$ X 100

Percent of eggs hatched in control

\section{Larvicidal bioassay}

Screening of the efficacy of methanol extract leaves of Saraca indica was done by performing bioassay studies against different developmental stages of Ostrinia nubilalis, Spodoptera littoralis, Callosobruchus maculatus and Tribolium confusum. The larvicidal activity of individual extract was assayed following the technique described earlier by Tong et al., (2013) and WHO guidelines (2005). According to the WHO protocol for larvicides testing for laboratory testing, batches of 20 numbers of healthy 4th instars larvae of each species were transferred to the disposable glasses with the depth between $5-10 \mathrm{~cm}$ having $100 \mathrm{ml}$ of water. A series of concentration from the 1000ppm to $10 \mathrm{ppm}$ were used to examine the larvicidal toxicity of the extract. The LC50 values are recorded after 24, 48 and 72 hour exposure. Each concentration was assayed in triplicate along with one negative control group in water and one positive control group with the DMSO. If the pupation occurred in the exposure time or more than $10 \%$ larva was died in the control group, the test was repeated. From the data, LC50 values were determined by probit analysis (SPSS 16).

\section{Statistical analysis}

All the experiments were conducted in replicates of three and data was recorded as mean value \pm SE. The statistical analysis was performed by one way analysis of variance and means were compared by least significance difference test $(\mathrm{P}<0.05)$ using the SPSS statistical software package (SPSS, ver. 10.0; Chicago. IL, USA). The correlation coefficient was calculated between dosemortality, dose-oviposition, dose-adult emergence, mortality-oviposition and oviposition-adult emergence using software Origin (Origin 6.0 Northampton, MA, USA). Further, the data was subjected to Student's ' $t$ ' 
test to analyzed the effect of Saraca indica extract on grain damage as well as weight loss of grains with control.

The data were corrected for the mortalities with the help of Abbott correction factor and were subjected to probit analysis using SPSS software to estimate LC50 values of effective methanol extract against the mosquito. Again, if mortality in the controls was found above $5 \%$, results with the treated samples were corrected using Abbott's formula (Abbott, 1925). The results obtained have been presented in Table 1-14.

The mortality (\%) was corrected using Abbott's formula (1925):

$$
\operatorname{Pr}=\frac{\text { Po }- \text { Pc }}{100-\text { Pc }}
$$

Where, $\mathrm{Pr}=$ Corrected mortality $(\%), \mathrm{Po}=$ Observed mortality (\%), Pc = Mortality in the control (\%). The results obtained have been presented in Table 1 to 14.

\section{Results and Discussion}

The fumigation efficacy of methanol extract of leaves of Saraca indica against four insect pests has been presented in Table 1 to 4 . From the result it is evident that the methanol extract of leaves of Saraca indica significantly protected all the four food commodities viz. Maize, Rice, Cowpea and Wheat on storage from insect pests such as Ostrinus nubilalsis, Spodoptera littoralis, Callosobruchus maculatus and Tribolium confusum ( $\mathrm{p}<0.05$; LSD) (Table 1-4). The feeding deterrent index (FDI) of $O$. nubilalsis, $S$. littoralis, $C$. maculatus and $T$. confusum on Maize infestation was $87.45 \%, 88.35 \%, 89.35 \%$ and $88.65 \%$ respectively; on Rice infestation was $88.55 \%, 89.654 \%, \quad 90.25 \%$ and $93.15 \%$ respectively; on Cowpea infestation was
$90.45 \%, \quad 91.35 \%, \quad 90.50 \%$ and $91.05 \%$ respectively and on Wheat infestation was $93.25 \%, 87.21 \%, \quad 93.45 \%$ and $87.35 \%$ respectively. There was $100 \%$ damage of all the four food commodities on storage in control experiment i.e. not fumigated with methanol extract of Saraca indica. In control experiment there was maximum loss in weight of food commodities. In case of Maize the loss was $47.25 \%$ to $48.45 \%$; of Rice it was 50.25 to $62.55 \%$; of Cowpea $28.45 \%$ to $58.90 \%$ and of Wheat $47.15 \%$ to $58.555 \%$ (Table 1- 4). All the four insect pests caused minimum damage to food commodities when fumigated with methanol extract of leaves of Saraca indica. The damage to maize grains by $O$. nubilalsis, Spodoptera littoralis, C. Callosobruchus maculatus and Tribolium confusum was $10.25 \%, \quad 10.35 \% \quad 9.75 \%$ and $10.45 \%$ respectively (Table 1). Similarly, the damage to rice grains by $O$. nubilalsis, Spodoptera littoralis, Callosobruchus maculatus and Tribolium confusum was $7.25 \%, 8.25 \%$, $6.35 \%$ and $3.68 \%$ respectively (Table 2 ). A more or less similar pattern of damage was noticed in cowpea and wheat by these insect pests after fumigation with methanol extract of leaves of Saraca indica (Table 3 and 4).

In the present study the methanol leaf extract of Saraca indica exhibited as botanical fumigant in protection of stored maize, rice, cowpea and wheat by enhancing feeding deterrence and reducing grain damage as well as weight loss of Ostrinus nubilalsis, Spodoptera littoralis, Callosobruchus maculatus and Tribolium confusum. The findings are in accordance with Kumar et al., (2007) and Varma and Dubey (2001) who investigated that essential oil of Cymbopogon martinii, Caesulia axillaris and Mentha arvensis protected stored gram and wheat from $C$. chinensis, S. oryzae and T. castaneum for first 12 months of storage. In the present investigation the shelf life of the Saraca indica extract in protection of insect 
infestation was 24 months thus more than the extract reported earlier. Plant extracts and essential oils are known to possess repellent, ovicidal and insecticidal activities against various stored grain insects (Hill and Schoonhoven 1981; Desmarchelier 1994). The present findings are also in agreement with the work of Rajesh et al., (2008) who have observed insecticidal activity Aegle marmelos essential oil against four stored grain insect pests viz. Callosobruchus chinensis, Rhyzopertha dominica, Sitophilus oryza, and Tribolium castaneum. Zaidur Rahmanolium Sabuj et al., (2017) have studied the control potential of Saraca indica extract against the adults of stored product pests Callosobruchus chunensis, Sitophilus oryzae and Tribolium castaneum and found a more or less similar result.

In the present investigation the ovicidal activity of the methanol extract of leaves of Saraca indica against four insect pests pest, no hatching of larvae were observed till 24 hours. Hatching of larvae were observed from 24 hours to 72 hours. No further hatching was recorded after 72 hour of treatment. Therefore LC50 value of ovicidal activity was recorded at 72 hour of exposure period (Table 5). At 10 ppm and after 72 hours of incubation $O$. nibilalsis, S. littoralis, $C$. maculatus and $T$. confusum the hatching percentage was $80.75 \%, \quad 78.51 \%, \quad 76.25 \%$ and $78.85 \%$ respectively. The hatching of larvae showed a decreasing trend on increasing the concentration of methanol extract of Saraca indica. At $1000 \mathrm{ppm}$ concentration of leaf extract and after $72 \mathrm{hrs}$ of incubation the hatching percentage of $O$. nibilalsis, $S$. littoralis, $C$. maculatus and T. confusum was $26.15 \%, 21.16 \%, 22.18 \%$ and $24.15 \%$ respectively (Table 5). The LC50 value along with the regression equation is listed in Table 6-9. The survivability of larvae of these insect pests has been indicated in Table 10. From the result it is evident that the larvae of all the four insect pests viz. Ostrinus nubilalsis, Spodoptera littoralis, Callosobruchus maculatus and Tribolium confusum survived at $10 \mathrm{ppm}$ concentration of methanol extract even after 72 hours of incubation. The survival percentage of the larvae of all the four insect pests decreased with increased concentration of methanol extract and with incubation period. At $1000 \mathrm{ppm}$ concentration of methanol extract of Saraca indica the larvae of these insect pests could not survive at any incubation time (Table 10).

In the present investigation the larvicidal activity of methanol extract of leaves of Saraca indica was studied against four insect pests viz. Ostrinus nubilalsis, Spodoptera littoralis, Callosobruchus maculatus and Tribolium confusum.

It was found that the larval mortality was directly related to the exposure time and concentration of the methanol extract (Table 11-14). For Ostrinus lubilalsis the LC50 values of the methanol extract at $24 \mathrm{~h}, 48 \mathrm{~h}$ and $72 \mathrm{~h}$ was recorded as $181.75 \mathrm{ppm}, 165.41 \mathrm{ppm}$ and $122.43 \mathrm{ppm}$ respectively (Table 11). For $S$. littoralis it was $179.65 \mathrm{ppm}, 161.45 \mathrm{ppm}$ and $121.35 \mathrm{ppm}$ respectively (Table 12); for $C$. maculatus $176.60 \mathrm{ppm}, 157.44 \mathrm{ppm}$ and $128.25 \mathrm{ppm}$ respectively (Table 13) and for $T$. confusum $180.75 \mathrm{ppm}, \quad 160.35 \mathrm{ppm}$ and $124.25 \mathrm{ppm}$ respectively (Table 14). The values of sub lethal concentrations are presented in Table 6-9.

In the present study, the methanol extract from the leaves of Saraca indica exhibited insecticidal activities against different developmental stages of the four target insect pests viz. Ostrinus nubilalsis, Spodoptera littoralis, Callosobruchus maculatus and Tribolium confusum. The findings revealed variation in the potentiality of the methanol extract in different development stages of the four insect pests. 
Table.1 Fumigant efficacy of methanol extract of leaves Saraca indica on stored maize against four insect pests at 500ppm

\begin{tabular}{|c|c|c|c|c|c|c|c|c|c|c|c|c|}
\hline \multirow[t]{2}{*}{ Treatment } & \multicolumn{3}{|c|}{ O. nubilalis } & \multicolumn{3}{|c|}{ S. littoralis } & \multicolumn{3}{|c|}{ C. maculatus } & \multicolumn{3}{|c|}{ T. confusum } \\
\hline & $\begin{array}{l}\text { Grain } \\
\text { damage } \\
(\%)\end{array}$ & $\begin{array}{l}\text { Weight } \\
\text { loss }(\%)\end{array}$ & FDI $(\%)$ & $\begin{array}{l}\text { Grain } \\
\text { damage } \\
(\%)\end{array}$ & $\begin{array}{l}\text { Weight } \\
\text { loss }(\%)\end{array}$ & FDI (\%) & $\begin{array}{l}\text { Grain } \\
\text { damage } \\
(\%)\end{array}$ & $\begin{array}{l}\text { Weight } \\
\text { loss }(\%)\end{array}$ & FDI (\%) & $\begin{array}{l}\text { Grain } \\
\text { damage } \\
(\%)\end{array}$ & $\begin{array}{l}\text { Weight } \\
\text { loss }(\%)\end{array}$ & FDI (\%) \\
\hline Extract & $\begin{array}{l}10.25^{\mathrm{a}} \\
\pm 0.31\end{array}$ & $\begin{array}{l}5.25^{\mathrm{a}} \\
\pm 0.21\end{array}$ & $\begin{array}{l}87.45 \\
\pm 0.70\end{array}$ & $\begin{array}{l}10.35^{\mathrm{a}} \\
\pm 0.31\end{array}$ & $\begin{array}{l}4.75^{\mathrm{a}} \\
\pm 0.34\end{array}$ & $\begin{array}{l}88.35 \\
\pm 0.18\end{array}$ & $\begin{array}{l}9.75^{\mathrm{a}} \\
\pm 0.21\end{array}$ & $\begin{array}{l}5.15^{\mathrm{a}} \\
\pm 0.71\end{array}$ & 89.35 & $\begin{array}{l}10.45^{\mathrm{a}} \\
\pm 0.31\end{array}$ & $\begin{array}{l}5.25^{\mathrm{a}} \\
\pm 0.15\end{array}$ & $\begin{array}{l}88.65 \\
\pm 0.35\end{array}$ \\
\hline control & $\begin{array}{l}100.00^{b} \\
\pm 0.00\end{array}$ & $\begin{array}{l}48.45^{b} \\
\pm 0.31\end{array}$ & & $\begin{array}{l}100.00^{b} \\
\pm 0.00\end{array}$ & $\begin{array}{l}47.25^{b} \\
\pm 0.41\end{array}$ & & $\begin{array}{l}100.00^{\mathrm{b}} \\
\pm 0.00\end{array}$ & $\begin{array}{l}47.25^{b} \\
\pm 0.13\end{array}$ & & $\begin{array}{l}100.00^{\mathrm{a}} \\
\pm 0.00\end{array}$ & $\begin{array}{l}47.75^{\mathrm{b}} \\
\pm 0.32\end{array}$ & \\
\hline
\end{tabular}

\pm : Standard Error; Means within each column followed by different letter are significantly different $(P<0.05$, student's $t$ test $)$

Table.2 Fumigant efficacy of methanol extract leavesof Saraca indica on stored Rice against four insect pests at 500ppm

\begin{tabular}{|c|c|c|c|c|c|c|c|c|c|c|c|c|}
\hline \multirow[t]{2}{*}{ Treatment } & \multicolumn{3}{|c|}{ O. nubilalis } & \multicolumn{3}{|c|}{ S. littoralis } & \multicolumn{3}{|c|}{ C. maculatus } & \multicolumn{3}{|c|}{ T. confusum } \\
\hline & $\begin{array}{l}\text { Grain } \\
\text { damage } \\
(\%)\end{array}$ & $\begin{array}{l}\text { Weight } \\
\text { loss }(\%)\end{array}$ & FDI (\%) & $\begin{array}{l}\text { Grain } \\
\text { damage } \\
(\%)\end{array}$ & $\begin{array}{l}\text { Weight } \\
\text { loss }(\%)\end{array}$ & FDI (\%) & $\begin{array}{l}\text { Grain } \\
\text { damage } \\
(\%)\end{array}$ & $\begin{array}{l}\text { Weight } \\
\text { loss }(\%)\end{array}$ & FDI (\%) & $\begin{array}{l}\text { Grain } \\
\text { damage } \\
(\%)\end{array}$ & $\begin{array}{l}\text { Weight } \\
\text { loss }(\%)\end{array}$ & FDI $(\%)$ \\
\hline Extract & $\begin{array}{l}7.25^{\mathrm{a}} \\
\pm 0.31\end{array}$ & $\begin{array}{l}3.65^{\mathrm{a}} \\
\pm 0.21\end{array}$ & $\begin{array}{l}88.55 \\
\pm 0.69\end{array}$ & $\begin{array}{l}8.25^{\mathrm{a}} \\
\pm 0.26\end{array}$ & $\begin{array}{l}3.15^{\mathrm{a}} \\
\pm 0.25\end{array}$ & $\begin{array}{l}89.65 \\
\pm 0.61\end{array}$ & $\begin{array}{l}6.35^{\mathrm{a}} \\
\pm 0.21\end{array}$ & $\begin{array}{l}3.45^{\mathrm{a}} \\
\pm 0.31\end{array}$ & 90.25 & $\begin{array}{l}3.68^{\mathrm{a}} \\
\pm 0.32\end{array}$ & $\begin{array}{l}1.25^{\mathrm{a}} \\
\pm 0.31\end{array}$ & $\begin{array}{l}93.15 \\
\pm 0.32\end{array}$ \\
\hline control & $\begin{array}{l}100.00^{b} \\
\pm 0.00\end{array}$ & $\begin{array}{l}62.55^{b} \\
\pm 0.27\end{array}$ & & $\begin{array}{l}100.00^{\mathrm{b}} \\
\pm 0.00\end{array}$ & $\begin{array}{l}61.55^{b} \\
\pm 0.41\end{array}$ & & $\begin{array}{l}100.00^{\mathrm{b}} \\
\pm 0.00\end{array}$ & $\begin{array}{l}50.25^{b} \\
\pm 0.12\end{array}$ & & $\begin{array}{l}100.00^{\mathrm{a}} \\
\pm 0.00\end{array}$ & $\begin{array}{l}55 . .35^{b} \\
\pm 0.30\end{array}$ & \\
\hline
\end{tabular}

\pm : Standard Error; Means within each column followed by different letter are significantly different $(P<0.05$, student's $t$ test $)$

Table.3 Fumigant efficacy of methanol extract of leaves Saraca indica on stored Cowpea against four insect pests at 500ppm

\begin{tabular}{|c|c|c|c|c|c|c|c|c|c|c|c|c|}
\hline \multirow[t]{2}{*}{ Treatment } & \multicolumn{3}{|c|}{ O. nubilalis } & \multicolumn{3}{|c|}{ S. littoralis } & \multicolumn{3}{|c|}{ C. maculatus } & \multicolumn{3}{|c|}{ T. confusum } \\
\hline & $\begin{array}{l}\text { Grain } \\
\text { damage } \\
(\%)\end{array}$ & $\begin{array}{l}\text { Weight } \\
\text { loss }(\%)\end{array}$ & FDI $(\%)$ & $\begin{array}{l}\text { Grain } \\
\text { damage } \\
(\%)\end{array}$ & $\begin{array}{l}\text { Weight } \\
\text { loss }(\%)\end{array}$ & FDI $(\%)$ & $\begin{array}{l}\text { Grain } \\
\text { damage } \\
(\%)\end{array}$ & $\begin{array}{l}\text { Weight } \\
\text { loss }(\%)\end{array}$ & FDI (\%) & $\begin{array}{l}\text { Grain } \\
\text { damage } \\
(\%)\end{array}$ & $\begin{array}{l}\text { Weight } \\
\text { loss }(\%)\end{array}$ & FDI (\%) \\
\hline Extract & $\begin{array}{l}4.35^{\mathrm{a}} \\
\pm 0.31\end{array}$ & $\begin{array}{l}0.53^{\mathrm{a}} \\
\pm 0.23\end{array}$ & $\begin{array}{l}90.45 \\
\pm 0.67\end{array}$ & $\begin{array}{l}3.15^{\mathrm{a}} \\
\pm 0.25\end{array}$ & $\begin{array}{l}0.55^{\mathrm{a}} \\
\pm 0.25\end{array}$ & $\begin{array}{l}91.35 \\
\pm 0.64\end{array}$ & $\begin{array}{l}6.55^{\mathrm{a}} \\
\pm 0.21\end{array}$ & $\begin{array}{l}3.25^{\mathrm{a}} \\
\pm 0.33\end{array}$ & 90.50 & $\begin{array}{l}2.25^{\mathrm{a}} \\
\pm 0.31\end{array}$ & $\begin{array}{l}0.56^{\mathrm{a}} \\
\pm 0.30\end{array}$ & $\begin{array}{l}91.05 \\
\pm 0.31\end{array}$ \\
\hline control & $\begin{array}{l}100.00^{b} \\
\pm 0.00\end{array}$ & $\begin{array}{l}58.50^{\mathrm{b}} \\
\pm 0.23\end{array}$ & & $\begin{array}{l}100.00^{b} \\
\pm 0.00\end{array}$ & $\begin{array}{l}28.45^{\mathrm{b}} \\
\pm 0.44\end{array}$ & & $\begin{array}{l}100.00^{b} \\
\pm 0.00\end{array}$ & $\begin{array}{l}40.25^{b} \\
\pm 0.16\end{array}$ & & $\begin{array}{l}100.00^{\mathrm{a}} \\
\pm 0.00\end{array}$ & $\begin{array}{l}37.32^{b} \\
\pm 0.22\end{array}$ & \\
\hline
\end{tabular}

\pm : Standard Error; Means within each column followed by different letter are significantly different $(P<0.05$, student's $t$ test $)$ 
Table.4 Fumigant efficacy of methanol extract of leaves of Saraca indica on stored Wheat against four insect pests at 500ppm

\begin{tabular}{|c|c|c|c|c|c|c|c|c|c|c|c|c|}
\hline \multirow[t]{2}{*}{ Treatment } & \multicolumn{3}{|c|}{ O. nubilalis } & \multicolumn{3}{|c|}{ S. littoralis } & \multicolumn{3}{|c|}{ C. maculatus } & \multicolumn{3}{|c|}{ T. confusum } \\
\hline & $\begin{array}{l}\text { Grain } \\
\text { damage } \\
(\%)\end{array}$ & $\begin{array}{l}\text { Weight } \\
\text { loss }(\%)\end{array}$ & FDI (\%) & $\begin{array}{l}\text { Grain } \\
\text { damage } \\
(\%)\end{array}$ & $\begin{array}{l}\text { Weight } \\
\text { loss }(\%)\end{array}$ & FDI (\%) & $\begin{array}{l}\text { Grain } \\
\text { damage } \\
(\%)\end{array}$ & $\begin{array}{l}\text { Weight } \\
\text { loss }(\%)\end{array}$ & FDI (\%) & $\begin{array}{l}\text { Grain } \\
\text { damage } \\
(\%)\end{array}$ & $\begin{array}{l}\text { Weight } \\
\text { loss }(\%)\end{array}$ & FDI $(\%)$ \\
\hline Extract & $\begin{array}{l}5.65^{\mathrm{a}} \\
\pm 0.31\end{array}$ & $\begin{array}{l}0.78^{\mathrm{a}} \\
\pm 0.21\end{array}$ & $\begin{array}{l}93.25 \\
\pm 0.65\end{array}$ & $\begin{array}{l}4.65^{\mathrm{a}} \\
\pm 0.23\end{array}$ & $\begin{array}{l}0.75^{\mathrm{a}} \\
\pm 0.25\end{array}$ & $\begin{array}{l}87.21 \\
\pm 0.63\end{array}$ & $\begin{array}{l}3.65^{\mathrm{a}} \\
\pm 0.22\end{array}$ & $\begin{array}{l}0.71^{\mathrm{a}} \\
\pm 0.31\end{array}$ & 93.45 & $\begin{array}{l}8.25^{\mathrm{a}} \\
\pm 0.30\end{array}$ & $\begin{array}{l}4.15^{\mathrm{a}} \\
\pm 0.31\end{array}$ & $\begin{array}{l}87.35^{\mathrm{a}} \\
\pm 0.31\end{array}$ \\
\hline control & $\begin{array}{l}100.00^{b} \\
\pm 0.00\end{array}$ & $\begin{array}{l}58.55^{\mathrm{b}} \\
\pm 0.27\end{array}$ & & $\begin{array}{l}100.00^{b} \\
\pm 0.00\end{array}$ & $\begin{array}{l}53.05^{\mathrm{b}} \\
\pm 0.42\end{array}$ & & $\begin{array}{l}100.00^{b} \\
\pm 0.00\end{array}$ & $\begin{array}{l}52.15^{\mathrm{b}} \\
\pm 0.17\end{array}$ & & $\begin{array}{l}100.00^{\mathrm{a}} \\
\pm 0.00\end{array}$ & $\begin{array}{l}47.50^{b} \\
\pm 0.21\end{array}$ & \\
\hline
\end{tabular}

\pm : Standard Error; Means within each column followed by different letter are significantly different $(P<0.05$, student's $t$ test $)$

Table.5 Hatching percentage of eggs of four insect pests after treatment of different concentration of Aegle marmelos leaf extract

\begin{tabular}{|c|c|c|c|c|c|c|c|c|c|c|c|c|c|}
\hline \multirow{2}{*}{$\begin{array}{l}\text { No. of } \\
\text { individuals } \\
150\end{array}$} & \multirow{2}{*}{$\begin{array}{l}\text { Conc } \\
\text { (ppm } \\
\text { (ppm }\end{array}$} & \multicolumn{3}{|c|}{ O. nubilalis } & \multicolumn{3}{|c|}{ S. littoralis } & \multicolumn{3}{|c|}{ C. maculatus } & \multicolumn{3}{|c|}{ T. confusum } \\
\hline & & 24 hour & 48 hour & 72 hour & 24 hour & 48 hour & 72 hour & $\begin{array}{l}24 \\
\text { hour }\end{array}$ & $\begin{array}{l}48 \\
\text { hour }\end{array}$ & 72 hour & 24 hour & $\begin{array}{l}48 \\
\text { hour }\end{array}$ & 72 hour \\
\hline & 10 & $\begin{array}{l}60.17 \\
\pm 1.17\end{array}$ & $\begin{array}{l}81.45 \\
\pm 1.15\end{array}$ & $\begin{array}{l}80.75 \\
\pm 1.17\end{array}$ & $\begin{array}{l}51.75 \\
\pm 1.26\end{array}$ & $\begin{array}{l}80.41 \\
\pm 1.27\end{array}$ & $\begin{array}{l}78.51 \\
\pm 1.07\end{array}$ & $\begin{array}{l}51.75 \\
\pm 1.19\end{array}$ & $\begin{array}{l}75.45 \\
\pm 1.27\end{array}$ & $\begin{array}{l}76.25 \\
\pm 1.31\end{array}$ & $\begin{array}{l}49.51 \\
\pm 1.09\end{array}$ & $\begin{array}{l}78.75 \\
\pm 1.25\end{array}$ & $\begin{array}{r}78.85 \\
\pm 1.17\end{array}$ \\
\hline & 100 & $\begin{array}{l}45.21 \\
\pm 1.15\end{array}$ & $\begin{array}{l}60.35 \\
\pm 1.16\end{array}$ & $\begin{array}{l}61.25 \\
\pm 1.17\end{array}$ & $\begin{array}{l}35.25 \\
\pm 1.27\end{array}$ & $\begin{array}{l}35.15 \\
\pm 1.37\end{array}$ & $\begin{array}{l}45.25 \\
\pm 1.08\end{array}$ & $\begin{array}{l}41.45 \\
\pm 1.14\end{array}$ & $\begin{array}{l}60.15 \\
\pm 1.16\end{array}$ & $\begin{array}{l}63.41 \\
\pm 1.32\end{array}$ & $\begin{array}{l}35.25 \\
\pm 1.15\end{array}$ & $\begin{array}{l}57.15 \\
\pm 1.32\end{array}$ & $\begin{array}{l}58.15 \\
\pm 1.17\end{array}$ \\
\hline & 500 & $\begin{array}{l}25.31 \\
\pm 1.13\end{array}$ & $\begin{array}{l}32.25 \\
\pm 1.14\end{array}$ & $\begin{array}{l}38.35 \\
\pm 1.17\end{array}$ & $\begin{array}{l}27.26 \\
\pm 1.19\end{array}$ & $\begin{array}{l}24.16 \\
\pm 1.15\end{array}$ & $\begin{array}{l}35.35 \\
\pm 1.21\end{array}$ & $\begin{array}{l}32.17 \\
\pm 1.16\end{array}$ & $\begin{array}{l}35.36 \\
\pm 1.10\end{array}$ & $\begin{array}{l}34.35 \\
\pm 1.30\end{array}$ & $\begin{array}{l}22.15 \\
\pm 1.17\end{array}$ & $\begin{array}{l}35.21 \\
\pm 1.31\end{array}$ & $\begin{array}{l}36.25 \\
\pm 1.17\end{array}$ \\
\hline & 1000 & $\begin{array}{l}15.27 \\
\pm 1.12\end{array}$ & $\begin{array}{l}21.35 \\
\pm 1.17\end{array}$ & $\begin{array}{l}26.15 \\
\pm 1.17\end{array}$ & $\begin{array}{l}17.41 \\
\pm 1.18\end{array}$ & $\begin{array}{r}18.50 \\
\pm 1.12\end{array}$ & $\begin{array}{l}21.16 \\
\pm 1.17\end{array}$ & $\begin{array}{l}17.15 \\
\pm 1.17\end{array}$ & $\begin{array}{l}21.17 \\
\pm 1.17\end{array}$ & $\begin{array}{l}22.18 \\
\pm 1.18\end{array}$ & $\begin{array}{l}19.35 \\
\pm 1.18\end{array}$ & $\begin{array}{l}21.45 \\
\pm 1.14\end{array}$ & $\begin{array}{l}24.15 \\
\pm 1.37\end{array}$ \\
\hline
\end{tabular}

Table.6 Ovicidal activity of Saraca indica leaf extract against Ostrinia nubilalis

\begin{tabular}{|l|l|l|l|l|l|}
\hline Ostrinia nubilalis & LC50 & $\begin{array}{l}\text { Regression } \\
\text { Equation }\end{array}$ & 95\% confidence level & Chi- square value \\
\hline Time & 280.75 & $\begin{array}{l}\text { Y }=3.86+ \\
0.54 X\end{array}$ & Lower Bound & Upper Bound & 72.15 \\
\hline
\end{tabular}


Table.7 Ovicidal activity of Saraca indica leaf extract against Spodoptera littoralis

\begin{tabular}{|l|l|l|l|l|l|}
\hline \begin{tabular}{l} 
Spodoptera littoralis \\
\hline Time
\end{tabular} & LC50 & $\begin{array}{l}\text { Regression } \\
\text { Equation }\end{array}$ & 95\% confidence level & Chi- square value \\
\hline 72 hours & 273.86 & $\begin{array}{l}\text { Y }=3.96+ \\
0.45 X\end{array}$ & Lower Bound & Upper Bound & 71.83 \\
\hline
\end{tabular}

Table.8 Ovicidal activity of Saraca indica leaf extract against Callosobruchus maculatus

\begin{tabular}{|l|l|l|l|l|l|}
\hline $\begin{array}{l}\text { Spodoptera littoralis } \\
\text { Time }\end{array}$ & LC50 & Regression Equation & 95\% confidence level & Chi- square value \\
\hline 72 hours & 282.85 & Y = 3.98+0.46X & Lower Bound & Upper Bound & 72.15 \\
\hline
\end{tabular}

Table.9 Ovicidal activity of Saraca indica leaf extract against Tribolium confusum

\begin{tabular}{|l|l|l|l|l|l|}
\hline Tribolium confusum & LC50 & Regression Equation & 95\% confidence level & Chi- square value \\
\hline Time & 286.75 & Y = 3.96+0.47X & Lower Bound & Upper Bound & 71.37 \\
\hline 72 hours & & & .370 & .517 & \\
\hline
\end{tabular}

Table.10 Survivability larvae of four insect pests after treatment of different concentration of Saraca indica leaf extract

\begin{tabular}{|c|c|c|c|c|c|c|c|c|c|c|c|c|c|}
\hline \multirow{2}{*}{$\begin{array}{l}\text { No. of individuals } \\
60\end{array}$} & \multirow{2}{*}{$\begin{array}{l}\text { Conc. } \\
\text { (ppm) }\end{array}$} & \multicolumn{3}{|c|}{ O. nubilalis } & \multicolumn{3}{|c|}{ S. littoralis } & \multicolumn{3}{|c|}{ C. maculates } & \multicolumn{3}{|c|}{ T. confusum } \\
\hline & & 24 hour & 48 hour & 72 hour & 24 hour & 48 hour & 72 hour & $\begin{array}{l}24 \\
\text { hour }\end{array}$ & $\begin{array}{l}48 \\
\text { hour }\end{array}$ & 72 hour & 24 hour & $\begin{array}{l}48 \\
\text { hour }\end{array}$ & 72 hour \\
\hline & 10 & $\begin{array}{l}100.00 \\
\pm 0.0\end{array}$ & $\begin{array}{l}100.00 \\
\pm 0.0\end{array}$ & $\begin{array}{l}100.00 \\
\pm 0.0\end{array}$ & $\begin{array}{l}100.00 \\
\pm 0.0\end{array}$ & $\begin{array}{l}100.00 \\
\pm 0.0\end{array}$ & $\begin{array}{l}100.00 \\
\pm 0.0\end{array}$ & 100.00 & $\begin{array}{l}100.00 \\
\pm 0.0\end{array}$ & $\begin{array}{l}100.00 \\
\pm 0.0\end{array}$ & $\begin{array}{l}100.00 \\
\pm 0.0\end{array}$ & $\begin{array}{l}100.00 \\
\pm 0.0\end{array}$ & $\begin{array}{l}100.00 \\
\pm 0.0\end{array}$ \\
\hline & 100 & $\begin{array}{l}85.21 \\
\pm 1.15\end{array}$ & $\begin{array}{l}75.05 \\
\pm 1.16\end{array}$ & $\begin{array}{l}65.15 \\
\pm 1.17\end{array}$ & $\begin{array}{l}82.25 \\
\pm 1.27\end{array}$ & $\begin{array}{l}78.15 \\
\pm 1.37\end{array}$ & $\begin{array}{l}67.08 \\
\pm 1.08\end{array}$ & $\begin{array}{l}83.45 \\
\pm 1.14\end{array}$ & $\begin{array}{l}71.15 \pm \\
1.16\end{array}$ & $\begin{array}{l}61.41 \\
\pm 1.32\end{array}$ & $\begin{array}{l}79.05 \\
\pm 1.15\end{array}$ & $\begin{array}{l}68.07 \\
\pm 1.32\end{array}$ & $\begin{array}{l}60.05 \\
\pm 1.17\end{array}$ \\
\hline & 500 & $\begin{array}{l}30.15 \\
\pm 1.13\end{array}$ & $\begin{array}{l}25.50 \\
\pm 1.14\end{array}$ & $\begin{array}{l}15.15 \\
\pm 1.17\end{array}$ & $\begin{array}{l}27.16 \\
\pm 1.19\end{array}$ & $\begin{array}{l}28.16 \\
\pm 1.15\end{array}$ & $\begin{array}{l}16.10 \\
\pm 1.21\end{array}$ & $\begin{array}{l}28.17 \\
\pm 1.16\end{array}$ & $\begin{array}{l}20.41 \pm \\
1.10\end{array}$ & $\begin{array}{l}14.25 \\
\pm 1.30\end{array}$ & $\begin{array}{l}31.00 \\
\pm 1.17\end{array}$ & $\begin{array}{l}26.07 \\
\pm 1.31\end{array}$ & $\begin{array}{l}15.15 \\
\pm 1.17\end{array}$ \\
\hline & 1000 & 0.0 & 0.0 & 0.0 & 0.0 & 0.0 & 0.0 & $\begin{array}{l}10.00 \\
\pm 1.17\end{array}$ & 0.0 & 0.0 & $\begin{array}{l}10.0 \\
\pm 1.18\end{array}$ & 0.0 & 0.0 \\
\hline
\end{tabular}


Table.11 Larvicidal activity of Saraca indica leaf extract against Ostrinia nubilalis

\begin{tabular}{|c|c|c|c|c|c|}
\hline \multicolumn{6}{|c|}{ Ostrinia nubilalis } \\
\hline Time & LC50 & Regression Equation & \multicolumn{2}{|c|}{$95 \%$ confidence level } & Chi- square value \\
\hline \multirow[t]{2}{*}{24 hours } & \multirow[t]{2}{*}{185.75} & \multirow[t]{2}{*}{$Y=-1.49+2.78 X$} & Lower Bound & Upper Bound & \multirow[t]{2}{*}{7.63} \\
\hline & & & 1.895 & 3.05 & \\
\hline 48 hours & 165.45 & $Y=-0.65+2.50 X$ & 1.73 & 2.79 & 8.07 \\
\hline 72 hours & 121.43 & $Y=-0.21+2.41 X$ & 1.63 & 1.95 & 6.85 \\
\hline
\end{tabular}

Table.12 Larvicidal activity of Saraca indica leaf extract against Spodoptera littoralis

\begin{tabular}{|c|c|c|c|c|c|}
\hline \multicolumn{6}{|c|}{ Spodoptera littoralis } \\
\hline Time & LC50 & Regression Equation & \multicolumn{2}{|c|}{$95 \%$ confidence level } & Chi- square value \\
\hline \multirow{2}{*}{24 hours } & \multirow[t]{2}{*}{179.65} & \multirow{2}{*}{$Y=-1.49+2.45 X$} & Lower Bound & Upper Bound & \multirow[t]{2}{*}{7.81} \\
\hline & & & 1.756 & 3.015 & \\
\hline 48 hours & 161.45 & $Y=-0.21+2.41 X$ & 1.87 & 3.04 & 8.02 \\
\hline 72 hours & 121.35 & $Y=-0.17+2.12 X$ & 1.76 & 2.82 & 6.87 \\
\hline
\end{tabular}

Table.13 Larvicidal activity of Saraca indica leaf extract against Callosobruchus maculatus

\begin{tabular}{|c|c|c|c|c|c|}
\hline \multicolumn{6}{|c|}{ Callosobruchus maculates } \\
\hline Time & LC50 & Regression Equation & \multicolumn{2}{|c|}{$95 \%$ confidence level } & Chi- square value \\
\hline \multirow[t]{2}{*}{24 hours } & \multirow[t]{2}{*}{176.60} & \multirow{2}{*}{$Y=-1.46+2.41 X$} & Lower Bound & Upper Bound & \multirow[t]{2}{*}{7.76} \\
\hline & & & 1.758 & 3.013 & \\
\hline 48 hours & 157.44 & $Y=-0.24+2.31 X$ & 1.85 & 3.02 & 8.07 \\
\hline 72 hours & 118.25 & $Y=-0.15+2.13 X$ & 1.71 & 2.80 & 6.90 \\
\hline
\end{tabular}

Table.14 Larvicidal activity of Saraca indica leaf extract against Tribolium confusum

\begin{tabular}{|c|c|c|c|c|c|}
\hline \multicolumn{6}{|c|}{ Tribolium confusum } \\
\hline Time & LC50 & Regression Equation & \multicolumn{2}{|c|}{$95 \%$ confidence level } & Chi-square value \\
\hline \multirow{2}{*}{24 hours } & \multirow{2}{*}{180.75} & \multirow{2}{*}{$Y=-1.51+2.80 X$} & Lower Bound & Upper Bound & \multirow[t]{2}{*}{7.51} \\
\hline & & & 1.90 & 3.01 & \\
\hline 48 hours & 160.35 & $Y=-0.59+2.48 X$ & 1.85 & 3.01 & 7.04 \\
\hline 72 hours & 124.25 & $Y=-0.25+2.50 X$ & 1.78 & 2.81 & 6.83 \\
\hline
\end{tabular}


The findings of the present investigation receive supports from works done by previous researchers. Works on S. indica extracts for insects mortality and repellency is scanty, however a lots of work have been done on larvicidal activity. The findings on the test insects mortality through this investigation are supported by Mathew et al., (2009) that revealed the Petroleum ether extract of $S$. indica leaves and the chloroform $(\mathrm{CHCl} 3)$ extract of the bark were effective against the larvae of Culex quinquefasciatus with respective LC50 values, 228.9 and 291.5ppm, which follows the WHO standard protocols. The results are also supported by Jinu and Jayabaskaran (2015), which yielded that the Pet. ether extract of $S$. indica leaves and $\mathrm{CHCl} 3$ extract of bark exhibited more than $50 \%$ larval mortality against $C$. quinquefasciatus larvae at an exposure period of $48 \mathrm{~h}$. No such reports have been reported so far on insect repellent activity of $S$. indica extract especially against the adults of the test insects. However, the findings by Singh et al., (2009) showed that $S$. indica leaves were effective against antibacterial activity where ethanol $(95 \%)$ and water extracts on agar plate $E$. coli, $S$. aureus by inhibitory effects on their growth which is similar to our findings in case of repellency test. However, another finding in the same experiments by Singh et al., (2009) showed that E. coli were found active whereas tested against $S$. aureus gave negative results. The findings of the present investigation also gets support from the findings of Sarojini et al., (2011) which revealed that the methanolic extracts were found relatively more potent as an anthelmintic agent due to presence of alkaloids. The mortality results also gets support from the findings of Verma et al., (2010) where $S$. indica methanolic leaves extracts showed that the central nervous system (CNS) of albino mice was depressant. The findings of the inhibitory or mortality results gets support from the findings by
Dabur et al., (2007) that the methanolic extracts of Saraca indica exhibited good inhibitory activity against $A$. canjani while it is effective at lower concentrations against other fungi also. The findings of Dubey et al., (2008) revealed that food grain losses due to insect infestation during storage are serious problem, particularly in the developing countries. It is estimated by Ahmed and Grainge, (1986) that more than 20,000 species of field and storage pests destroy approximately one-third of the world's food production, valued annually at more than $\$ 100$ billion among which the highest losses (43\%) occurring in the developing world. The present investigation was carried out against Ostrinia nubilalis (European corn borer), Spodoptera littoralis (Cotton leaf worm), Callosobruchus maculates (cowpea seed beetle) and tribolium confusum (Confused flour beetle) to yield promising fumigating and insecticidal activity as all the four insects are stored product pests and they cause a huge damage in stored products and ultimately cause economic damage. Moreno \& Racelis, (2015) finds out that repellency is the system tends to dissuade pests away from a susceptible crop (repellent) what can be called a push approach and our findings in controlling these pests gets support from it. Thus, plants are natural source of these repellent agents, reported in several ethno botanical information. Ali et al., (2017) concluded that plant-derived repellents or insecticides do not pose hazards of toxicity to humans and domestic animals, and are easily biodegraded compared to synthetic compounds, natural products are presumed to be safer for humans. The extracts of $S$. indica leaves can be used in the control of these stored product pests as the results of the investigation showed both repellency and mortality against the test insect pests. This study was attempted to highlight $S$. indica claimed to be used or associated with insect repellent and mortality activity, and it was 
found considerable. However, test result on other attributes also support the present finding, such as mortality and repellency for the extracts of $S$. indica against stored product pests.

Stored products cover a major portion of agricultural products but several species of insects infest these in storage condition and causing a huge damage. Using plants with insecticidal properties is therefore an attractive alternative to save them in comparison to the more expensive synthetic pesticides. Various plants by-products have been tried recently with a good degree of success as protectants against a number of stored grain insect pests. The findings of the present study indicate the ovicidal and larvicidal efficacy of extracts of $S$. indica on Ostrinia nubilalis (European corn borer), Spodoptera littoralis (Cotton leaf worm), Callosobruchus maculates (cowpea seed beetle) and Tribolium confusum (Confused flour beetle)

\section{Acknowledgement}

Authors are thankful to Dr Baidyanath Kumar, Visiting Professor, Department of Biotechnology, Patna Science College, Patna (Patna University) for providing necessary suggestions.

\section{References}

Abbott WS. (1925): A method of computing the effectiveness of an insecticide. Journal of Economic Entomology. 18(2):265-267.

Adedire CO, Akinneye JO. (2004): Biological activity of tree marigold, Tithonia diversifolia, on cowpea seed bruchid, Callosobruchus maculatus (Coleoptera: Bruchidae). Ann. Appl. Biol. 144:185189.
Ahmed S, Grainge M. (1986): Potential of the Neem tree (Azadirachta indica) for pest control and rural development. Journal of Economic Botany. 40(2):201-209.

Ali H, Sabiha S, Islam S, Rekha SB, Nesa M, Islam N. (2017): Repellent activity of Argemone mexicana L. extracts against Aphis gossypii Glover and Tribolium castaneum (Hbst.) adults. Journal of Pharmacognosy and Phytochemistry. 6(1):466-469.

Ali M. (2008): Text Book of Pharmacognosy. New Delhi, CBS Publishers \& Distributors. 3:668-669.

Arivoli, S., S. Tennyson, Larvicidal and adult emergence inhibition activity of Abutilon indicum (Linn.) (Malvaceae) leaf extracts against vector mosquitoes (Diptera: Culicidae), Journal of Biopesticides, Vol.4, No.1, 27 - 35, 2011.

Arlian, LG. (2002): Arthropod allergens and human health. Annu. Rev. Entomol.47:395-433.

Arthur FH, Throne JE. (2003): Efficacy of diatomaceous earth to control internal infestations of rice weevil and maize weevil (Coleoptera: Curculionidae). $J$. Econ. Entomol. 96:510-518.

Athanassiou CG, Kavallieratos NG. (2005): Insecticidal effect and adherence of PyriSec ${ }^{\circledR}$ in different grain commodities. Crop Prot. 24:703-710.

Athanassiou CG, Kontodimas DK, Kavallieratos NG, Anagnou-Veroniki M. (2005): Insecticidal effect of NeemAzal against three stored product beetle species on rye and oats. J. Econ. Entomol. 98:1733-1738.

Babu A, Hern A, Dorn S. (2003): Sources of semiochemicals mediating host findings in Callasobruchus chinensis (Coleoptera: Bruchidae). Bull. Entomol. Res. 93:187-192.

Begum SN, Ravikumar K, Ved DK. (2014): 'Asoka' -an important medicinal plant, 
its market scenario and conservation measures in India. Current Science. 107(1):26-28.

Dabur R, Gupta A, Mandal TK, Singh DD, Bajpai V, Gurav AM (2007): Antimicrobial activity of some Indian medicinal plants. African Journal of Traditional, Complementary and Alternative Medicines. 4(3): 313-318.

Desmarchelier JM. (1994): Grain protectants: trends and developments. In: Stored Product Protection Vol. 2. Highley E, Wright EJ, Banks HJ, Champ BR (Eds) CAB International, Wallingford, UK. pp 722-728.

Dubey NK, Kumar R, Tipathi P. (2004): Global Promotion of herbal medicine: India's oppoliunity. Curr. Sci. (India) 86:37-41.

Dubey NK, Srivastava B, Kumar A. (2008): Current status of plant products as botanical pesticides in storage pest management. Journal of Biopesticide. 1(2):182-186.

French RC. (1985): The bioregulatory action of flavour compounds on fungal spores and other propagules. Annu. Rev. Phytopathol. 23:173-199.

Hartmans KJ, Diepenhorst P, Bakker W, Gorris LGM. (1995): The use of carvone in agriculture, sprout suppression of potatoes and antifungal activity against potato tuber and other plant diseases. Ind. Crop Prod. 4:3-13.

Hill JM, Schoonhoven AV, (1981): The use of vegetable oils in controlling insect infestations in stored grains and pulses. Recent Advan. Food Sci. Technol. 1: 473-481.

Ho SH, Ma Y, Goh PM, Sim KY. (1995): Star anise, Illicium verum Hook $\mathrm{f}$. as a potential grain protectant against Tribolium castaneum Herbst and Sitophilus zeamais Motsch. Postharvest. Biol. Tech. 6:341-347.
Holley AH, Patel H. (2005): Improvement in shelf life and safety of perishable foods by plant essential oils and smoke antimicrobials. Int. J. Food Microbol. 22:273-292.

Hubert J, Stejskal V, Munzbergova Z, Kubatova A, Vanova M, Zd'arkova E. (2004): Mites and fungi in heavily infested stores in the Czech Republic. $J$. Econ. Entomol. 97(6): 2144-53.

Isman MB, Koul O, Luezynski N. (1990): Insecticidal and antifeedant bioactivity of neem oil and their relationship to azadirachtin content. J. Agric. Food Chem. 38:1406-1411.

Jain SK. Medicinal Plants. New Delhi, National Book Trust. 1968, 124.

Jenkins DA, Dunkel FV, Gamby KT. (2003): Storage temperature of Neem kernel extract: differential effects on oviposition deterrency and larval toxicity of Callosobruchus maeulatus (F.) (Coleoptera: Bruchidae). Environ. Entomol. 32:1283- 1289.

Jinu MV, Jayabaskaran C. Diversity and anticancer activity of endophytic fungi associated with the medicinal plant Saraca asoca. Current Research in Environmental \& Applied Mycology. 2015; 5(3):169-179.

Kokate CK, Gokhale AS, Gokhale SB. Cultivation of Medicinal Plants. 1st ed. Pune, Nirali Prakashan. 2007; 7(13):3637.

Kumar R, Srivastava M, Dubey NK. (2007): Evaluation of Cymbopogon martinii oil extract for control of post-harvest insect deterioration in cereal and pulse. $J$. Food Prot. 70: 172-178.

Mathew N, Anitha MG, Bala TSL, Sivakumar SM, Narmadha R, Kalayansundaram M. Larvicidal activity of Saraca indica, Nyctanthes arbor-tristis, and Clitoria ternatea extracts against three mosquito vector species. Springer Link. 2009; 104:1017-1025. 
Mishra A, Kumar A, Rajbhar N, Kumar A. Phytochemical and pharmacological importance of Saraca indica. International Journal of Pharmaceutical and Chemical Science. 2013; 2(2):10091013.

Mishra AK, Dubey NK (1994): Evaluation of some essential oils for their toxicity against fungi causing deterioration of stored food commodities. Appl. Environ. Microbiol. 60: 1401-1405.

Mollik MAH, Hossan MS, Paul AK, TaufiqUr-Rahman, Jahan $\mathrm{R}$ and Rahmatullah M. A Comparative analysis of medicinal plants used by folk medicinal healers in three districts of Bangladesh and inquiry as to mode of selection of medicinal plants. A Journal of Ethnobotany Research \& Applications. 2010; 8:195-218.

Mondal KAMSH, Port GR. (1994): Pheromones of Tribolium spp and their potential in pest management. Agricul. Zool. Rev. 6:121-148.

Moreno CR, Racelis AE. Attraction, repellence and predation: role of companion plants in regulating Myzus persicae (Sulzer) (Hemiptera: Aphidae) in organic Kale Systems of South Texas. Southwestern Entomologist. 2015; 40(1):1-14.

Parkin EA. (1956): Stored Product Entomology (the assessment and reduction of losses caused by insects to stored food stuffs). Annu. Rev. Entomol. 1:233-240.

Perez-Mendoza J, Throne JE, Dowell FE, Baker JE. (2004): Chronological agegrading of three species of storedproduct beetles by using near-infrared spectroscopy. J. Econ. Entomol. 97:1159-1167.

Phillips JK, Burkholder WE. (1984): Health hazards of insects and mites in food. Insect Management for Food Storage and Processing, In: Braur F (ed.) The

\section{American Association of Cereal} Chemists, pp. 280-292.

Prajapati ND, Purohit SS, Sharma AK, Kumar TA. Hand Book of Medicinal Plants. 1st ed. Agrobios, India. 2003, 460-461.

Pushpanathan, T.A., M. Govindarajan, (2006): Larvicidal, ovicidal and repellent activities of Cymbopogan citratusStapf (Graminae) essential oil against the filarial mosquito Culex quinquefasciatus (Say) (Diptera: Culicidae), Tropical Biomedicine, Vol. 23, No.2, 208-212,

Rajesh Kumar, Ashok Kumar, Chandra Shekhar Prasa1, Nawal Kishore Dubey and Raju Samant (2008): Insecticidal Activity Aegle marmelos (L.) Correa Essential Oil Against Four Stored Grain Insect Pests, Internet Journal of Food Safety, Vol.10, p.39-49

Sarojini N, Manjari SA, Kanti CC. Phytochemical screening and anthelmintic activity study of Saraca indica leaves extracts. International Research Journal of Pharmacy. 2011; 2(5):194-197.

Saxena RC, Dixit OP, Harshan V. (1992): Insecticidal action of Lantana camara against Callosobruchus chinensis (Coleoptera: Bruchidae). J Stored Prod. Res. 28:279-281.

Shaaya E, Kostjukovski M, Eilberg I, Sukprakarn C. (1997): Plant oils as fumigants and contact insecticides for the control of stored- product insects. $J$. Stored Prod. Res. 33: 7-15.

Singh A, Singh S, Sarma BK, Singh UP, Srivastava R, Singh KP. Phenolic acid analysis and biological activity of methanolic extract of some medicinal plants against some phytopathogenic fungi. Internet Journal of Alternative Medicine. 2009; 6(2):1-20.

Tennyson, S., K. J. Ravindran, S. (2011): Arivoli, Screening of plant extracts for ovicidal activity against Culex 
quinquefasciatus Say (Diptera:

Culicidae), Applied Botany, Vol. 40, 5456-5460,

Tong, F., J.R. Bloomquist, (2013): Plant Essential Oils Affect the Toxicities of Carbaryl and Permethrin against Aedes aegypti (Diptera: Culicidae), Journal of Medical Entomology, Vol. 50, N0. 4, 826-832, 2013

Varma J, Dubey NK. (1999): Prospectives of botanical and microbial products as pesticides of tomorrow. Curr Sci (India) 76:172-179.

Varma J, Dubey NK. (2001): Efficacy of essential oils of Caesulia axillaris and Mentha arvensis against some storage pests causing biodeterioration of food commodities. Int. J. Food Microbiol. 68:207-210.

Verma A, Jana GK, Sen S, Chakraborty R, Sachan S, Mishra A. Pharmacological evaluation of Saraca indica leaves for central nervous system depressant activity in mice. Scientific Research
Journal of Pharmacology. 2010; 2(6):338-343.

Ward SM, Delaquis PJ, Holley RA, Mazza G. (1998): Inhibition of spoilage and pathogenic bacteria on agar and precooked roasted beef by volatile horse radish distillates. Food Res. Int. 31:1926.

WHO guidelines for laboratory and field testing of mosquito larvicides. (2005): 13.

Wilbur DA, Mills RB. (1978): Stored Grain Insects. In: Pfadt RE (Ed), Fundamentals of Applied Entomology, Macmillan Publishing Company, New York USA.

Zaidur Rahman Sabuj, Sadequl Islam, Samiul Haque, Shahina Begum Rekha and Nurul Islam (2017): Control potentials of Saraca indica L. extracts against the adults of stored product pests Callosobruchus chinensis L., Sitophilus oryzae L. and Tribolium castaneum (Hbst.), Journal of Entomology and Zoology Studies, 5(4): 11-15

\section{How to cite this article:}

Savita, Rimhim Sheel, Baidyanath Kumar and Kumari Snehlata. 2018. Insecticidal Efficacy of Methanol Extract of Leaves of Saraca indica L. against Four Insect Pests Causing Severe Damage to Stored Grains. Int.J.Curr.Microbiol.App.Sci. 7(06): 1205-1220.

doi: https://doi.org/10.20546/ijcmas.2018.706.143 